\title{
CHARACTER EDUCATION OF FOOD LOCAL CULTURE VALUES IN THE PEOPLE OF KAMPUNG ADAT CIRENDEU IN WEST JAVA THROUGH EXEMPLARY
}

\author{
Rohmatulloh, Aan Hasanah, Uus Ruswandi \\ Graduate School of Islamic Education, UIN Sunan Gunung Djati- Bandung \\ rohmatulloh@esdm.go.id
}

\begin{abstract}
Customary village is small group of people who still survive and consistently preserve the culture and belief of their ancestors. Local cultural values deserve to be promoted to the application of character education in school. The qualitative research understanding the life and local cultural values is carried out in the people of Kampung Adat Cirendeu in West Java. The local culture of the Kampung Adat Cirendeu people holds the principle of ngindung ka waktu and mibapa ka jaman which has the meaning of maintaining identity but still keeping abreast of the times. One of the local cultural values that still preserves until today is the culture of cassava-based food as a substitute for rice. This culture has been going on for a century and become an inspiration for the national food diversification program. One of the preservation efforts is through the example of their ancestors. Promotion and granting food culture values to the character education in schools involve various educational stakeholders that should give an example to the students. The most effective method is to form students with character and in the end they will be familiar with local food culture and does not depend on rice.
\end{abstract}

Keywords: Character education, Kampung Adat Cirendeu, Exemplary

\section{PENDIDIKAN KARAKTER NILAI-NILAI BUDAYA LOKAL MAKANAN DI MASYARAKAT KAMPUNG ADAT CIRENDEU JAWA BARAT MELALUI KETELADANAN}

\begin{abstract}
Abstrak: Desa adat adalah sekelompok kecil orang yang masih bertahan dan secara konsisten melestarikan budaya dan kepercayaan nenek moyang mereka. Nilai-nilai budaya lokal layak dipromosikan untuk penerapan pendidikan karakter di sekolah. Penelitian kualitatif yang memahami kehidupan dan nilai-nilai budaya lokal ini dilakukan pada masyarakat Kampung Adat Cirendeu di Jawa Barat. Budaya lokal masyarakat Kampung Adat Cirendeu memegang prinsip ngindung ka waktu dan mibapa ka jaman yang memiliki makna mempertahankan identitas tetapi tetap mengikuti perkembangan zaman. Salah satu nilai budaya lokal yang masih dipertahankan hingga saat ini yaitu budaya makanan berbasis singkong
\end{abstract}


sebagai pengganti beras. Budaya ini telah berlangsung selama satu abad dan menjadi inspirasi bagi program diversifikasi pangan nasional. Salah satu upaya pelestariannya yaitu melalui contoh dari nenek moyang mereka. Promosi dan penanaman nilai budaya pangan lokal pada pendidikan karakter di sekolah melibatkan banyak pemangku kepentingan pendidikan yang harus memberikan peneladanan pada peserta didik. Metode peneladanan paling efektif untuk membentuk peserta didik berkarakter dan pada akhirnya terbiasa dengan budaya pangan lokal yang tidak tergantung pada beras.

Kata kunci: Pendidikan karakter, Kampung Adat Cirendeu, teladan.

\section{INTRODUCTION}

Kampung Adat Cirendeu is one of the people of thirteen groups of Sundanese tribes who still adhere to local cultural values and Sundanese beliefs. Research about local cultural values of Kampung Adat Cirendeu has been carried out from various aspects, that are the local food culture of cassava tubers as a substitute for rice (Fadhilah, 2014; Saleha, 2005; Saraswati \& Gulfa, 2017), the custom value as the basis for people empowerment (Nabhan, 2017), the process of transforming value of form and meaning because of changing times (Nurharyanto, Wildan, \& Alia, 2016), the application of the value of local wisdom to learning resources for social science (Widyanti, 2015), and the value of local culture as an inspiration to design the Cimahi batik (Rosandini \& Noorrahmi, 2016).

Research on aspect of the value of the local Kampung Adat Cirendeu food culture (Saraswati \& Gulfa, 2017) discusses the value of the local food culture of the Kampung Adat Cirendeu people in term of the concept of food security (Fadhilah, 2014), discusses the existence of the culinary tradition of cassava rice which is influenced by habit and belief, and the environmental adaptation of agricultural land. Whereas Saleha, (2005) discussed the habits of Kampung Adat Cirendeu people and studied them from various aspects, that are social, cultural, and economic. Meanwhile, there has been no research that addresses the problem of how the value of the local food culture of Kampung Adat Cirendeu is promoted and internalized to students through the exemplary method, but actually this aspect is very important and in line with government programs that are looking for solutions to national food problems. So that the consumption pattern of the Indonesian people who tend to the pattern of single food consumption in the form of rice can change their habits slightly using other raw materials such as tubers 
(Ariani, 2010).

In the current context, the local food culture of the Kampung Adat Cirendeu people has been an inspiration for the birth of central and regional government policies as stated in West Java Governor Regulation No. 60 year 2010 concerning acceleration of food diversification based on local resource food. Although the background of the policy is not the same as the background of the Kampung Adat Cirendeu people, the program has the same goal to accustom the consumption of staple foods other than rice as an alternative. The City Government of Depok since 2012 implemented a food diversification program with its popular term "One day no rice". The success of this program was further carried out by other regional governments, one of them is the City of Bandung. The program's campaign has been carried out since 2015 until now in Junior High School for the formation of young generation characters (Dinas Komunikasi dan Informatika, 2018; Jabarnews, 2018; Pikiran Rakyat, 2015). Effort to cultivate character value to achieve the desired one day no rice program are certainly not just done through teaching method. Other methods such as exemplary from government official, teacher, and other education stakeholder including the Kampung Adat Cirendeu people must be involved to be an example in promoting the local food culture values for student. A good exemplary method is the most effective way of cultivate character value for student.

Researchs on local wisdom in Indonesia are very important for character education, especially for lower class people in Indonesia who highly uphold local cultures that had valuable values. In the studies of character education, many local cultures in Indonesia have been used as examples and mirrors to strengthen national culture. Some examples can be explained here for example puppet culture (Dwijonagoro et al, 2019), Maja Labo Dahu culture (Mulyadin \& Jaedun, 2019), and Andong culture (Prasetyo \& Marzuki, 2019). These local cultures are very important for character education in Indonesia, which continues to explore the values of local culture that are still stored.

The main objective of this study is to discuss the value of local Kampung Adat Cirendeu food culture which is used as one of the values of character education for students through exemplary. This main objective is divided into three objectives, that are: 1) understanding the life and cultural values, especially the local food culture that deserve to be promoted as the value of character education in school; 2) to discuss method of character education exemplary and its 
application in the education of local food culture values of Kampung Adat Cirendeu people in the school environment; and 3) identifying stakeholder related to character education to be actively involved in giving example to student.

\section{METHODS}

This study discusses the culture and belief of an indigenous group, then the approach used is qualitative strategy (Creswell, 2009). The process of collecting data (interview and observation) at the village location and documentation. This type of research is also called descriptive, because only trying to discuss and convey information systematically related to the culture of people (Kumar, 2011). The research stage uses the following stages: 1) Identifying all the customary villages in West Java Province. 2) Determine the people group of the customary villages that are the object of study. 3) An understanding of the local cultural values of the Kampung Adat Cirendeu people that was chosen at the beginning was based on the results of documentation of previous research. 4) Determining the focus of research on local food culture values that other researchers have not yet discussed, that is aspect of character education through exemplary in schools. 5) Direct understanding of the value of local culture and local food culture with customary administrator at the Kampung Adat Cirendeu location. 6) Mapping stakeholder in West Java Province who are involved in the character education of the local food culture value of Kampung Adat Cirendeu people to student.

All stages use research methods, that are the collection, analysis and presentation of data. Primary data collection used a type of direct interview with Kampung Adat Cirendeu people administrators. Interviews were conducted at the Kampung Adat Cirendeu custom hall using voice recorder and camera to take pictures. The author also observes the environment around Kampung Adat Cirendeu related to road facilities, houses, and others, as well as seeing the customary and sports activities of the people, especially mothers and children. Secondary data collection from documentation material to enrich the author's knowledge obtained from institution reports, electronic news clippings, scientific journals that discuss previous research on the cultural values of Kampung Adat Cirendeu society, and reference books.

Data analysis and interpretation is carried out during the process and after completion of data collection. Data analysis during data collection was carried out by writing on field notebook and documentation source. While the data analysis at the time of the data 
collection was done by replaying the interview record. Data were analyzed based on the group theme of local cultural value of Kampung Adat Cirendeu, the value of local food culture, and map of stakeholders involved in the context of implementing character education in

\section{FINDINGS AND DISCUSSION}

\section{Finding}

\section{Local Culture Value of Kampung Adat Cirendeu}

Kampung Adat Cirendeu is geographically located in the administrative area of South Cimahi District, Leuwigajah Village. The Kampung Adat Cirendeu people is a school. Data from the analysis are presented using narrative, and image to facilitate understanding of the results of the study. Image creation using system modeling software tools. Research findings are interpreted using the exemplary character education method.

Sundanese tribe group that still holds firm and preserve the local valus or culture and belief of Sunda Wiwitan. The Kampung Adat Cirendeu people has a local cultural value which is known as their principle that are ngindung ka waktu, mibapa ka jaman as presented in Figure 1.

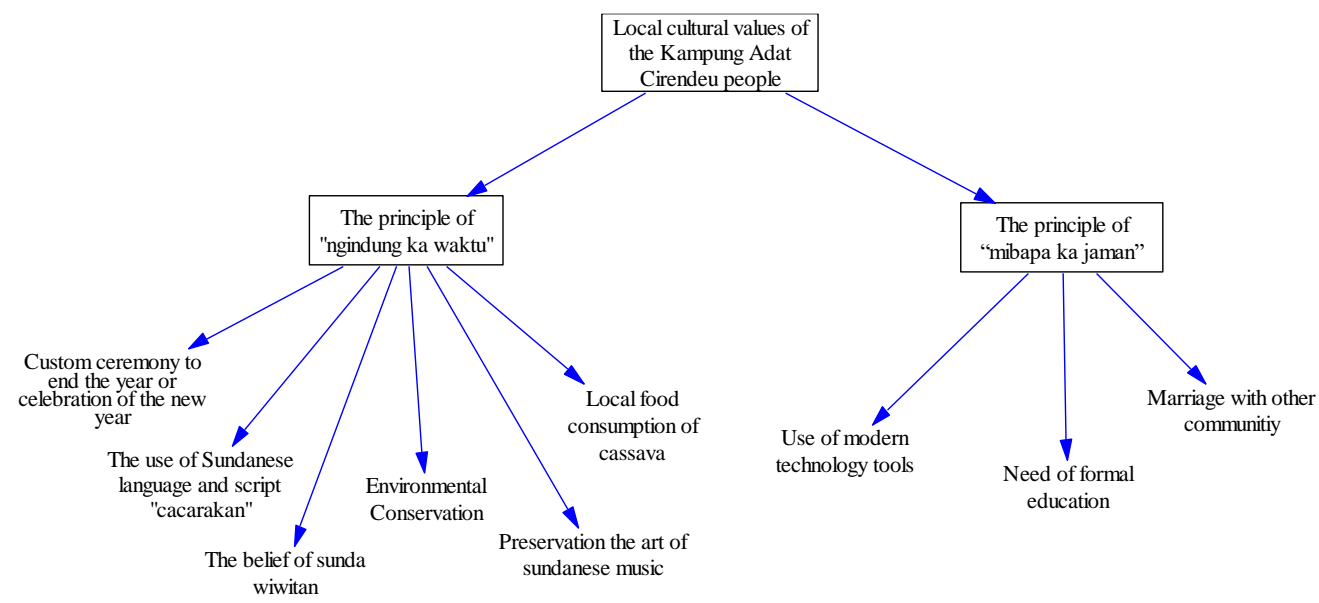

Figure 1. Local cultural values of the Kampung Adat Cirendeu people

The principle of ngindung $k a$ waktu means that the Kampung Adat Cirendeu people in their belief has their own way and characteristic of belief (Fadhilah, 2020). This principle is internalized and preserved till now in the form, that are: 1) The custom ceremony to end the year. When the author conducts an interview, the customary administrator shows a banner commemorating the custom 
ceremony that reads "Tutup taun 1950 ngemban taun 1 sura 1951 saka sunda, mugia akur rukun repeh rapih sareng sasama hirup". The Kampung Adat Cirendeu people year is younger than the calculation of the year and older than the calculation of the Islamic year. 2) Use of Sundanese language and cacarakan script as a communication tool. 3) The belief of Sunda Wiwitan that they adhered so that the people did not belong to the official religion recognized by the government 4) Preservation the art music of sundanese that use musical instruments such as angklung, karinding, kecapi suling, and calung 5) Environmental conservation by dividing the area into three functions, that are leuweung larangan (protected forest), leuweung tutupan (buffer forest), and leuweung baladahan (production forest) (Fadhilah, 2020; Saraswati \& Gulfa, 2017), 6) Consumption of local food derived from carbohydrate sources of cassava as a substitute for rice.

While the principle of mibapa ka jaman implies that society will not oppose the changing times (Fadhilah, 2014). This principle is internalized and preserved till now in the form, that are: 1) The use of modern technology tools to meet their needs such as the use of electrical energy sources provided by electricity service provider, and electronic household appliance such as washing machine, rice cooker, cooling machine, and others. 2) Fulfillment of educational needs for people who are permitted public and religious schools outside the Kampung Adat Cirendeu environment. 3) Allow marriage with other people outside the adherents of the cultural values and teachings adopted by Kampung Adat Cirendeu. The implementation of the principle of mibapa ka jaman does not make a concern for the sustainability of the local culture of the Kampung Adat Cirendeu people, because in the Kampung Adat Cirendeu environment there is always an effort to internalize the local cultural values especially to the young generation who have done a lot of activities that come into contact with modern culture and other people outside environment outside Kampung Adat Cirendeu.

The teaching of values in the Kampung Adat Cirendeu people is carried out through the strengthening of local cultural values through various media, that are: 1) Sharing knowledge with elders. This forum is called surasa. This surasa was carried out at Kampung Adat Cirendeu custom bale to discuss the various problems faced by the Kampung Adat Cirendeu people both personal and custom institution. 2) Customary education provided according to level. The initial level is given Sundanese literacy and culture lessons. The next level is given spiritual lessons, values to give awareness as a Sundanese. 3) 
Teaching or dogma called pamali when eating rice. 4) directly and imitate it consciously. By giving an example, the young generation of Kampung Adat Cirendeu people have an awareness of applying the cultural value of their local food.

\section{Local Food Culture}

The value of the local culture of the Kampung Adat Cirendeu people that the author try to study on one of the cultural values to promote its cultural value is the value of the local food culture of the Kampung Adat Cirendeu people. This local food culture has made Kampung Adat Cirendeu known to people outside Kampung Adat Cirendeu and the government as food independent villages in 2007. Independent food village are the title of village given because the people have the ability to realize food and nutrition security through the development, distribution and consumption subsystem with utilize local resources in a sustainable manner (Saraswati \& Gulfa, 2017).

Judging from its history, the ancestors of Kampung Adat Cirendeu used local food instead of rice to become cassava has been done since 1918. In 2018, the tradition of local food of the Kampung Adat Cirendeu people has reached the age of a century or a hundred years. The local food raw material for cassava is a selfproduced based on the land's condition (dry land). While the rice produced by Kampung Adat Cirendeu is sold out of Kampung Adat Cirendeu to become saving. For the Kampung Adat Cirendeu people there is no prohibition from the traditional management to consume rice. But it also does not mean allowing to consume rice. The young generation of Kampung Adat Cirendeu society realize that consuming cassava local food is a tradition that must be followed after learning from the history of their ancestors. Their ancestors at that time had two reasons for making cassava as a substitute for rice, that are the historical context at that time (1918) and the presence of sawangan or foresight from their ancestors.

The reason related to the historical context was at the time of the rice crisis because the Dutch colonial had monopolized rice, there was a failure to harvest rice plants, and did not want to depend on others. These three reasons trigger the ancestors to stop totally consuming rice. The transition period from 1918 to 1924 was a difficult time and not easy to pass. During these six years, traditional technology was found to process cassava or to become cassava rice. In modern technology it is called analog rice which uses granulation and extrusion method. This technology can process non-rice ingredients in such a way that they have characteristics such as rice that have physical properties of grain, 
rice making and texture (Budi, Hariyadi, Budijanto, \& Syah, 2013). The traditional technology of processing cassava into cassava rice delivered them to got an awarded a food hero in 1964. This local food culture continues to be preserved to this day and makes the attention of the central government to give appreciation. The Ministry of Agriculture pushed to the national level to become a food diversification program in 2005 . The government since introduced the Kampung Adat Cirendeu people to other parties as examples of consuming food other than rice can be done and have a positive impact, especially in terms of economic aspects.

The reason related to existence of the sawangan of their ancestors, the people of kampung adat cirendeu have belief that pamali or taboo to consume rice. The famous philosophy of the Kampung Adat Cirendeu people from their ancestors is "Teu boga sawah asal boga pare, teu boga pare asal boga beas, teu boga beas asal nyangu, teu nyangu asal dahar, teu dahar asal kuat" (We don't have rice field as long as we have rice, we don't have rice as long as we have rice, we don't have rice as long as we can cook rice, we can't eat rice as long as we can eat, we can't eat as long as it can be strong). So that there is no dependence on one of the staple foods. The term eating is not only full but a source of strength even if only with one corn seed.

\section{Discussion}

The value of local food culture based on cassava tuber has become one of the characteristic of the Kampung Adat Cirendeu people that has been instilled by their ancestors and has proven to be one of the advantages of the village in supporting food security. According to the Indonesian Dictionary, culture is the mind, reason, customs, something that has become a habit that has been difficult to change. According to Samuel P Huntington, cultural understanding is the same as value (Harrison \& Huntington, 2000). The definition of value according to (Halstead \& Taylor, 2005) are principle, basic belief, ideal, standard or attitude that act as general guideline for behavior or as reference point in decision making or evaluation of belief or action and that are closely related to personal integrity and personal identity. This character value needs to be promoted to student as the Bandung City Government did in junior high school. This recognition of cultural values is part of a character education program. Therefore, it is necessary to discuss in advance the understanding of character education itself.

The definition of education is a variety of efforts made by educator toward student in order to achieve 
positive maximum development through teaching, habituation, exemplary, and other endeavors (Tafsir, 2013). Understanding character according to the Moral Education Handbook, character is a daily habit of someone (Power, Nuzzi, Narvaez, Lapsley, \& Hunt, 2008). According to the Indonesian Dictionary, character is the nature or psychological characteristic, character that distinguish someone from others. Based on these meanings, it can be concluded that character already a behavior in a person and a differentiator with others. Understanding character education according to the Moral Education Handbook is a value learning process that has implication in a life and decisions are made (Power et al., 2008). Issues of character education are popular in the United States, while in other countries the terms used vary because of differences in theoretical perspective (Berkowitz, 2002). In the concept of Islamic education, education to develop the character of student is called akhlak education. Akhlak education is understood as theologically as a religious obligation ordered by Allah Almighty. Thus it is not based on the demand of the times. But the implementation still follows the development of space and time (Hasanah, 2013).

Character education programs are carried out through various activities, that are teaching, exemplary, habituation, motivating, and enforcing rules (Hasanah, 2013). The concept of exemplary in Islamic education is called uswatun hasanan (al-uswah al-hasanah) or a good example. Theologically, this good exemplary concept can be found in several verses that contain the word al-uswah or exemplary, that are Sura al-Ahzab [33]: 21. Furthermore (Shihab, 2011) in his interpretation explain that the problem of exemplification in the letter Ahzab [33]: 21 is divided into two, that are exemplary for problems related to religion activity or religion teaching. First, the problem of religion activity (pray) according to him is a must or obligatory to follow what has been exemplified by the Prophet. Second, the Prophet's study of the world problems was recommended and submitted entirely to the experts in charge of each. But there are also other views which state that world job must also follow the Prophet.

This verse is the basis for one of the method in delivering Islamic education material contained in a character education curriculum. Exemplary method to promote and cultivate the value of local food culture of Kampung Adat Cirendeu people in character education must be carried out by someone who is an example or role model for student, especially teachers. The teacher as a special figure has an obligation of developing cognitive, psychomotor, and affective that student have. The 
teacher as the center of attention becomes the model to be example. Therefore the teacher must have akhlak or character criteria referring to the example of the Prophet of Islam, that is the Prophet Muhammad PBUH. Because education must be seen as a system consisting of the interrelationships of various component and other actors, another figure called educational stakeholder also must be involved in providing examples. In the context of the education system, stakeholder involved as described (Sallis, 2002) include internal and external stakeholder. Internal stakeholders are education staff and teacher as previously explained. While external stakeholders are student, parent of students and governor, and the labor market, government, people.

Furthermore,

eleven stakeholders must be involved to provide an education in the character of local food culture in addition to rice are presented as in Figure 2. When the local food culture program is implemented in schools (for example Thursday), all stakeholders must demonstrate their example to students. For example the school canteen manager on the day did not provide rice-based food, but based on tubers (cassava, potatoes, etc.). The government such as the Regional Head up to the regional apparatus organization provides an example by visiting schools and exemplifying consuming food items other than rice. Likewise with teachers and other education personnel. This character education if carried out properly by all stakeholders will produce benefits and impacts in the medium and long term Medium-term benefits are students accustomed to the local food culture of tubers at home and society. While the longterm impact supports the success of food diversification programs in West Java and nationally.

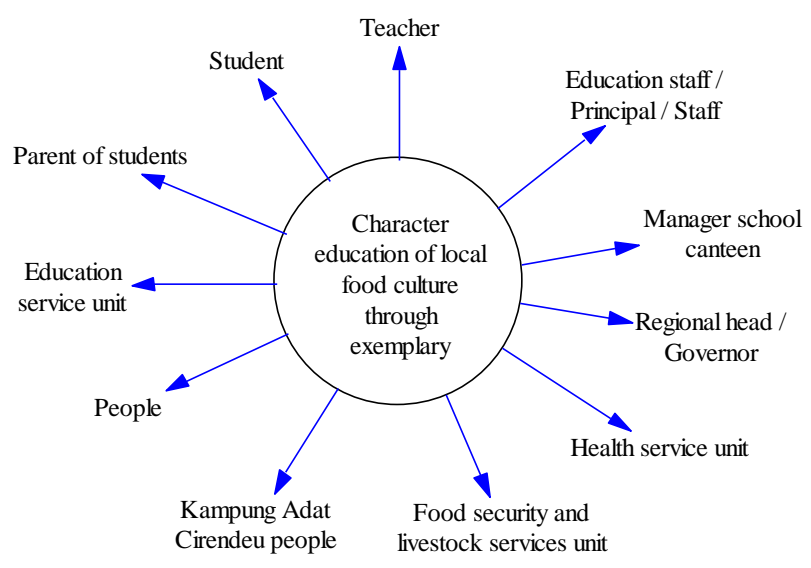

Figure 2. Map of stakeholders 


\section{CONCLUSION}

The value of local food culture is one of the legacies of Kampung Adat Cirendeu's ancestors that are still preserved until now. The cultural value of cassava-based local food as a substitute for rice has been a century old and has been instilled through forums of knowledge sharing, custom education, exemplary giving, and the delivery of teaching or dogma. The promotion of the value of local food culture needs to be done in schools through a method of character education that has proven effective in instilling values. Exemplary character values must be carried out by all education stakeholders (teachers, education staff, government, people, and indigenous people) so that students can imitate the good examples. The success of planting this value in the medium term can change the cultural habit of food that do not always depend on rice commodities and in the long run support people participation in food diversification programs in West Java and nationally.

\section{ACKNOWLEDGMENT}

The author would like to thank of the Editorial in Chief dan Reviewer of Jurnal Pendidikan Karakter, Dr. Marzuki, for the constructive input for the improvement of this article and finally it is worthy of being published in this journal.

\section{REFERENCES}

Ariani, M. (2010). Diversifikasi konsumsi pangan pokok mendukung swasembada beras. In Prosiding Pekan Serealia Nasional (pp. 65-73).

Berkowitz, M. W. (2002). The science of character education. In W. Damon (Ed.), Bringing in a New Era in Character Education (pp. 43-63). California: Hoover Institution Press.

Budi, F. S., Hariyadi, P., Budijanto, S., \& Syah, D. (2013). Teknologi proses ekstrusi untuk membuat beras analog. Pangan: Media Komunikasi Dan Informasi, 22(3), 263-274. Retrieved from https://www.academia.edu/3201 5516/Teknologi_Proses_Ekstrus i_untuk_Membuat_Beras_Anal og.

Creswell, J. W. (2009). Research design: Qualitative, quantitative, and mixed methods approaches (Third). Thousand Oaks: SAGE Publications.

Dinas Komunikasi dan Informatika. (2018). Pemkot Bandung resmikan gerakan One Day No Rice. Retrieved June 22, 2018, from

https/portal.bandung.go.id/posts /2015/08/21/PyDa/pemkotbandung-resmikan-gerakan-oneday-no-rice

Dwijonagoro, S., Meilawati, A., Nurhidayati, N., Wulan, S.H. 
(2019). Pendidikan karakter dalam lakon Banjaran Bima dan implikasinya dalam pendidikan, Jurnal Pendidikan Karakter, 9(2), 133-151.

DOI: https://doi.org/10.21831/jp k.v9i2.24981.

Fadhilah, A. (2014). Budaya pangan anak singkong dalam himpitan modernisasi pangan: eksistensi tradisi kuliner rasi (beras singkong) komunitas kampung adat Cireundeu Leuwi Gajah Cimahi Selatan Jawa Barat. AlTurâs, 20(1), 11-23. DOI. 10.15408/bat.v20i1.3742.

Halstead, J. M., \& Taylor, M. J. (Eds.). (2005). Values in education and education in values. London: Taylor \& Francis e-Library.

Harrison, L. E., \& Huntington, S. P. (Eds.). (2000). Culture matters: How values shape human progress. New York: Basic Book.

Hasanah, A. (2013). Pendidikan karakter berperspektif Islam. Bandung: Insan Komunika.

Jabarnews. (2018, April 18). One Day No Rice, Apakah Itu? Jabarnews.Com. Retrieved from http://jabarnews.com/2018/04/o ne-day-no-rice-apakah-itu.html

Kumar, R. (2011). Research methodology, a step-by-step guide for beginners (Third). London: SAGE Publications.

Mulyadin, M. \& Jaedun, J. (2019). Semboyan maja labo dahu dalam pendidikan karakter. Jurnal Pendidikan Karakter, 9(2), 204-215. DOI: https://doi.org/10.21831/jp k.v9i2.22311.

Nabhan, R. A. (2017). Pemberdayaan masyarakat berbasis nilai adat (studi kasus pada masyarakat adat Cirendeu Cimahi Jawa Barat). Ciputat: UIN Syarif Hidayatullah.

Nurharyanto, P., Wildan, D., \& Alia, M. N. (2016). Transformasi Nilai-Nilai Kearifan Lokal Masyarakat Adat Cireundeu. Jurnal Pendidikan Sosiologi, 6(1).

Pikiran Rakyat. (2015). SMPN 13 Bandung pilot project sekolah program "One Day No Rice." Pikiran Rakyat. Retrieved from http://www.pikiranrakyat.com/pendidikan/2015/08/ 20/339173/smpn-13-bandungpilot-project-sekolah-programone-day-no-rise.

Power, F. C., Nuzzi, R. J., Narvaez, D., Lapsley, D. K., \& Hunt, T. C. (Eds.). (2008). Moral education: A handbook. Volumes 1 \& 2. London: Praeger.

Prasetyo, N., Marzuki, M. (2019). Nilai-nilai karakter pada teknik patri tapal kuda lampu andong di Kotagede Yogyakarta. Jurnal Pendidikan Karakter, 9(1), 104115.

DOI: https://doi.org/10.21831/jp k.v0i1.23588. 
Rosandini, M., \& Noorrahmi, R. (2016). Developing Batik Cimahi by re-designing color and batik motif of traditional Village Cirendeu, Cimahi, West Java, Indonesia. International E-Journal of Advances in Social Sciences, 2(5), 560-569. DOI: 10.18769/ijasos.72746.

Saleha, Q. (2005). Kajian pola dan kebiasaan makan masyarakat Cireundeu di Kelurahan Leuwigajah, Kecamatan Cimahi, Kabupaten Bandung. EPP, 2(1), 22-28. Retrieved from https://docplayer.info/31475480 -Kajian-pola-dan-kebiasaanmakan-masyarakat-cireundeudi-kelurahan-leuwigajahkecamatan-cimahi-kabupatenbandung.html.

Sallis, E. (2002). Total quality management in education (Third edit). London: Kogan
Page Ltd.

Saraswati, \& Gulfa, R. P. (2017). Kearifan budaya lokal kampung adat Cirendeu dan konsep swasembada pangan. Prosiding Seminar Nasional Perencanaan Pembangunan Inklusif DesaKota (pp. 451-458). Padang: Universitas Andalas.

Shihab, M. Q. (2011). Tafsir alMisbah: Pesan, kesan, dan keserasian al-Qur'an. Jakarta: Penerbit Lentera Hati.

Tafsir, A. (2013). Ilmu pendidikan Islami. Bandung: PT Remaja Rosdakarya.

Widyanti, T. (2015). Penerapan nilainilai kearifan lokal dalam budaya masyarakat kampung adat Cirendeu sebagai sumber pembelajaran IPS. Jurnal Pendidikan Ilmu Sosial, 24(2), 161-166.

DOI: https://doi.org/10.17509/jp is.v24i2.1452. 